\title{
Protective role of Populus tomentiglandulosa against hydrogen peroxide-induced oxidative stress in SH-SY5Y neuronal cells
}

\author{
Yu Ri Kwon' (D) - Ji Hyun Kim² (D) Sanghyun $\mathrm{Lee}^{3}$ (D) $\cdot$ Eun Ju Cho ${ }^{1}$ (D) \\ Hyun Young Kim²
}

Received: 18 October 2020 / Accepted: 28 October 2020 / Published Online: 31 December 2020

(C) The Korean Society for Applied Biological Chemistry 2020

\begin{abstract}
Oxidative stress caused by the overproduction of reactive oxygen species (ROS) is known as an etiology of neurodegenerative diseases. Populus tomentiglandulosa (PT), a member of the Salicaceae family, is widely grown in Korea and has been reported to exert protective effects on cerebral ischemia by attenuating of oxidative stress and neuronal damage. In the present study, we investigated the antioxidant activity and neuroprotective effects of an ethanol extract and four fractions [ $n$-butanol, ethyl acetate (EtOAc), chloroform, and $n$-hexane] of PT under in vitro and cellular systems. The extract and four fractions of PT showed 1,1diphenyl-2-picrylhydrazyl (DPPH), ${ }^{\circ} \mathrm{OH}$, and $\mathrm{O}_{2}^{-}$radical scavenging activities in a dose-dependent manner. In particular, the EtOAc fraction of PT had the strongest $\mathrm{DPPH},{ }^{\circ} \mathrm{OH}$, and $\mathrm{O}_{2}^{-}$radical scavenging activities among the extract and other fractions. Therefore, we further investigated the neuroprotective effect of the EtOAc fraction of PT against oxidative stress in $\mathrm{H}_{2} \mathrm{O}_{2}$-induced $\mathrm{SH}-\mathrm{SY} 5 \mathrm{Y}$ cells. Treatment with $\mathrm{H}_{2} \mathrm{O}_{2}$ significantly decreased cell viability and lactate dehydrogenase (LDH) release, and it also increased the ROS levels compared to the normal group. However, treatment with the EtOAc fraction of PT significantly
\end{abstract}

Eun Ju Cho $(\bowtie)$

E-mail: ejcho@pusan.ac.kr

Hyun Young $\operatorname{Kim}(\bowtie)$

E-mail: hykim@gntech.ac.kr

${ }^{1}$ Department of Food Science and Nutrition, Pusan National University, Busan 46241, Republic of Korea

${ }^{2}$ Department of Food Science, Gyeongnam National University of Science and Technology, Jinju 52725, Republic of Korea

${ }^{3}$ Department of Plant Science and Technology, Chung-Ang University, Anseong 17546, Republic of Korea

This is an Open Access article distributed under the terms of the Creative Commons Attribution Non-Commercial License (http://creativecommons. org/licenses/by-nc/3.0/) which permits unrestricted non-commercial use, distribution, and reproduction in any medium, provided the original work is properly cited. increased cell viability. Moreover, the EtOAc fraction of PTtreated group significantly suppressed ROS production and LDH release compared to the $\mathrm{H}_{2} \mathrm{O}_{2}$-induced control group. In conclusion, our findings indicated that PT had in vitro antioxidant activity and neuroprotective effects against oxidative stress. Therefore, PT could be used as a natural agent for protection against oxidative stress.

Keywords Hydrogen peroxide $\cdot$ Neuronal damage Oxidative stress $\cdot$ Populus tomentiglandulosa $\cdot$ Reactive oxygen species

\section{Introduction}

Free radicals are typically unstable compounds containing a single unpaired electron, which is naturally generated in the body [1]. Free radicals have beneficial effects such as on the immune response, but the overproduction of free radicals can damage biological molecules such as lipids, proteins, and DNA in the body [2]. Reactive oxygen species (ROS) are representative free radicals and include hydroxyl radicals $\left({ }^{\circ} \mathrm{OH}\right)$, superoxide ions $\left(\mathrm{O}_{2}^{-}\right)$, and hydrogen peroxide $\left(\mathrm{H}_{2} \mathrm{O}_{2}\right)$ [3]. The overproduction of ROS can induce oxidative stress, an imbalance between the production of oxidants and their elimination, and oxidizes essential cell components such as cell membranes and cell organelles $[4,5]$. Therefore, oxidative stress is closely related to the pathogenesis of various diseases such as cancer, diabetes, cardiovascular disease, and neurodegenerative diseases [6,7].

The nervous system has relatively less well-developed protective mechanisms against oxidative stress compared to other tissues, thereby brain and neuronal cells are vulnerable to oxidative stress [8]. In the brain, several components such as excitatory amino acids and neurotransmitters induce oxidative stress by producing ROS. In addition, mitochondria in the brain use a large amount of oxygen in the process of generating energy, hence the brain 
produces more free radicals than other tissues and is continually exposed to oxidative stress [9]. Oxidative stress in the brain is strongly associated with the progression of neuronal injury and death, leading to neurodegenerative diseases such as Alzheimer's disease and Parkinson's disease [7]. Many studies have investigated the development of antioxidants that can protect neuronal oxidative stress for preventing neurodegenerative diseases induced by oxidative stress.

Populus tomentiglandulosa (PT), a member of the Salicaceae family, is widely grown in Korea and is a hybrid between $P$. alba and P. davidiana [10]. P. alba and P. davidiana have been reported to have various biological activities such as antioxidant, antiinflammatory, hepatoprotective, and vasorelaxant effects [11-13]. In addition, several studies have reported that the ethanol $(\mathrm{EtOH})$ extract of PT had antioxidant activity demonstrated by 1,1diphenyl-2-picrylhydrazyl (DPPH) and 2,2'-azino-bis (3-ethylbenzothiazoline-6-sulfonic acid) (ABTS) radical scavenging activities in vitro, and also elevated antioxidant enzymes such as superoxide dismutase and glutathione peroxidase in rats $[14,15]$. The EtOH extract of PT contains several phenolic compounds such as catechin, caffeic acid, $p$-coumaric acid, chlorogenic acid, and gallic acid [14]. Furthermore, several neuroprotective effects of PT have been reported, which protected neurons from ischemic damage and cerebrovascular disorders $[15,16]$. However, the antioxidant activity and neuroprotective effects against oxidative stress of various extracts and fractions of PT have not been yet studied.

The present study investigated the in vitro antioxidant activity of an EtOH extract and four fractions such as $n$-butanol $(\mathrm{BuOH})$, ethyl acetate (EtOAc), chloroform $\left(\mathrm{CHCl}_{3}\right)$, and $n$-hexane (hexane) of PT. In addition, we evaluated the neuroprotective effect of active fraction of PT against oxidative stress in $\mathrm{H}_{2} \mathrm{O}_{2}$ induced SH-SY5Y neuronal cells.

\section{Materials and Methods}

\section{Reagents}

1,1-Diphenyl-2-picrylhydrazyl (DPPH), 2-deoxyribose, 3-(4,5dimethylthiazol-2-yl)-2,5-diphenyltetrazolium bromide (MTT), dimethyl sulfoxide (DMSO), and 2',7'-dichloro-fluorescein diacetate (DCF-DA) were purchased by Sigma Chemical Co. (St. Louis, MO, USA). EtOH was acquired from Duksan Co. Ltd. (Ansan, Korea). $\mathrm{FeSO}_{4} \cdot 7 \mathrm{H}_{2} \mathrm{O}$ was obtained from Daejung Chemicals \& Metals Co. Ltd. (Gyeonggi, Korea). Phosphoric acid was obtained from Samchun Pure Chemical Co. Ltd. (Gyeonggi, Korea). Hydrochloric acid and $\mathrm{H}_{2} \mathrm{O}_{2}$ were purchased from Junsei Chemical Co. (Tokyo, Japan). Trichloroacetic acid (TCA) and thiobarbituric acid (TBA) were supplied by Biosesang Inc. (Seongnam, Korea) and Acros Organics, Inc. (Morris Plains, NJ, USA). Phenazine methosulfate (PMS), nitrotetrazolium blue chloride (NBT), and nicotinamide adenine dinucleotide $(\mathrm{NADH})$ were obtained from
Bio Basic, Inc. (Amherst, NY, USA). Tris was purchased from the LPS Solution Co. (Daejeon, Korea). Dulbecco's modified Eagle's medium (DMEM), penicillin-streptomycin, fetal bovine serum (FBS), and trypsin-EDTA solution were purchased from Welgene, Inc. (Daegu, Korea).

\section{Preparation of the samples}

The dried leaves of PT $(1442.6 \mathrm{~g})$ were extracted with EtOH under reflux three times $\left(86^{\circ} \mathrm{C} 3 \mathrm{~h}\right)$, and this extract was combined and evaporated to afford a brown residue $(278.3 \mathrm{~g})$. Then, the residue was suspended in distilled water and partitioned sequentially with $\mathrm{BuOH}$ (59.9 g), EtOAc (36.0 g), $\mathrm{CHCl}_{3}$ (35.5 g), and hexane (45.7 g). Subsequently, the extract and four fractions were dissolved in DMSO and used for the experiments.

\section{1,1-Diphenyl-2-picrylhydrazyl (DPPH) radical scavenging assay} We investigated the DPPH radical scavenging activity of PT following the method of Hatano et al. [17]. The extract and four fractions of PT were diluted in $\mathrm{EtOH}$, and the diluted solutions were mixed with $60 \mu \mathrm{M}$ DPPH in a 1:1 ratio in a 96-well plate. The plate was incubated in the dark at room temperature for 30 min, the absorbance was read at $540 \mathrm{~nm}$ using a microplate reader (Thermo Fisher Scientific, Vantaa, Finland). Using the absorbance value, the DPPH radical scavenging activity was calculated as follows:

DPPH radical scavenging activity $(\%)=\left[\left(\mathrm{A}_{\text {control }}-\mathrm{A}_{\mathrm{PT}}\right) / \mathrm{A}_{\text {control }}\right] \times 100$

( $\mathrm{A}_{\mathrm{PT}}$ means the absorbance of PT and $\mathrm{A}_{\text {control }}$ means the absorbance of the control)

\section{Hydroxyl radical ( $\mathrm{OH})$ scavenging assay}

The ${ }^{\circ} \mathrm{OH}$ radical scavenging activity of PT was evaluated using the method described by Chung et al. [18]. In the dark, $1400 \mu \mathrm{L}$ of extract and four fractions from PT were mixed with $200 \mu \mathrm{L}$ of $10 \mathrm{mM} \mathrm{FeSO} 4 \cdot 7 \mathrm{H}_{2} \mathrm{O}$-EDTA, $200 \mu \mathrm{L}$ of $10 \mathrm{mM}$ 2-deoxyribose solution, and $200 \mu \mathrm{L}$ of $10 \mathrm{mM} \mathrm{H}_{2} \mathrm{O}_{2}$. The mixed solutions were incubated at $37{ }^{\circ} \mathrm{C}$ for $4 \mathrm{~h}$, and then $1 \mathrm{~mL}$ of $1 \%$ TBA and $1 \mathrm{~mL}$ of $2.8 \%$ TCA were added. The mixtures were boiled for $20 \mathrm{~min}$ and cooled on ice. The absorbance of the mixture in a 96-well plate was read at an absorbance of $490 \mathrm{~nm}$ using a microplate reader. The ${ }^{\circ} \mathrm{OH}$ radical scavenging activity was calculated as follows:

$\cdot \mathrm{OH}$ radical scavenging activity $(\%)\left[\left(\mathrm{A}_{\text {control }}-\mathrm{A}_{\mathrm{PT}}\right) / \mathrm{A}_{\text {control }}\right] \times 100$

( $\mathrm{A}_{\mathrm{PT}}$ means the absorbance of PT and $\mathrm{A}_{\text {control }}$ means the absorbance of the control)

\section{Superoxide radical $\left(\mathrm{O}_{2}^{-}\right)$scavenging assay}

The $\mathrm{O}_{2}^{-}$radical scavenging activity of PT was determined according to the method of Ewing and Janero [19]. Briefly, $500 \mu \mathrm{L}$ of the extract and four fractions of PT were added to $100 \mu \mathrm{L}$ of $0.1 \mathrm{M}$ Tris- $\mathrm{HCl}$ (pH 7.4), $200 \mu \mathrm{L}$ of $0.1 \mathrm{mM}$ PMS, $200 \mu \mathrm{L}$ of $0.5 \mathrm{mM}$ 
NBT, and $400 \mu \mathrm{L}$ of $0.5 \mathrm{mM} \mathrm{NADH}$, and then reacted at room temperature for $10 \mathrm{~min}$. The mixed solutions were measured at an absorbance of $560 \mathrm{~nm}$ using a microplate reader. The $\mathrm{O}_{2}{ }^{-}$radical scavenging activity was calculated as follows:

$$
\mathrm{O}_{2}{ }^{-} \text {radical scavenging activity }(\%)\left[\left(\mathrm{A}_{\text {control }}-\mathrm{A}_{\mathrm{PT}}\right) / \mathrm{A}_{\text {control }}\right] \times 100
$$

( $\mathrm{A}_{\mathrm{PT}}$ means the absorbance of PT and $\mathrm{A}_{\text {control }}$ means the absorbance of the control)

\section{Cell culture}

SH-SY5Y neuronal cells were obtained from the Korea Cell Line Bank (KCLB, Seoul, Korea). The SH-SY5Y cells were cultured in T-75 flasks containing DMEM supplemented with 10\% FBS and $1 \%$ penicillin-streptomycin. The incubator used for cell culture maintained an atmosphere of $5 \% \mathrm{CO}_{2}$ at $37{ }^{\circ} \mathrm{C}$. The cells were fed once every two days with fresh medium. The cells were sub-cultured at $80 \%$ confluency using $0.05 \%$ trypsin-EDTA.

\section{Measurement of cell viability}

Cell viability was measured using the MTT assay [20]. The SHSY5Y cells were plated at a density of $2.5 \times 10^{5}$ cells $/ \mathrm{mL}$ onto $96-$ well plates, and incubated for $24 \mathrm{~h}$. The cells were treated with the EtOAc fraction of PT at various concentrations (1, 5, and $10 \mu \mathrm{g} /$ $\mathrm{mL}$ ), and incubated for $2 \mathrm{~h}$. Afterward, $500 \mu \mathrm{M} \mathrm{H}_{2} \mathrm{O}_{2}$ was added. After $24 \mathrm{~h}$ of incubation, $200 \mu \mathrm{L}$ of MTT solution $(5 \mathrm{mg} / \mathrm{mL})$ was added to the cells to form crystals. After $4 \mathrm{~h}, 200 \mu \mathrm{L}$ of DMSO was added to the cells to dissolve the incorporated formazan crystals. The absorbance of each well was measured at $540 \mathrm{~nm}$ using a microplate reader.

\section{Measurement of reactive oxygen species (ROS) production} ROS production was measured using the DCFH-DA assay [21]. SH-SY5Y cells were seeded at $2.5 \times 10^{5}$ cells $/ \mathrm{mL}$ in a 96 -well black plate and incubated for $24 \mathrm{~h}$. Subsequently, the cells were pretreated with the EtOAc fraction of PT at different concentrations $(1,5$, and $10 \mu \mathrm{g} / \mathrm{mL})$ for $2 \mathrm{~h}$. After, the cells were treated with 500 $\mu \mathrm{M} \mathrm{H} \mathrm{H}_{2} \mathrm{O}_{2}$ for $24 \mathrm{~h}$. Then, the cells were treated with $80 \mu \mathrm{M}$ of DCF-DA and incubated for $30 \mathrm{~min}$ and the absorbance of each well was read at at excitation and emission wavelengths of 480 $\mathrm{nm}$ and $535 \mathrm{~nm}$, respectively, for $60 \mathrm{~min}$ using a fluorescence spectrophotometer (FLUOstar OPTIMA, BMG Labtech, Ortenberg, Germany).

Measurement of lactate dehydrogenase (LDH) release activity The LDH release assay was conducted using the LDH Cytotoxicity Detection Kit (Takara Bio, Shiga, Japan). The SH-SY5Y cells were seeded at a density of $2.5 \times 10^{5}$ cells $/ \mathrm{mL}$ in a 96 -well plate and incubated for $24 \mathrm{~h}$. Then, the cells were pretreated with the EtOAc fraction of PT at various concentrations (1, 5, and $10 \mu \mathrm{g} /$ $\mathrm{mL}$ ) and treated with $500 \mu \mathrm{M} \mathrm{H}_{2} \mathrm{O}_{2}$. After $24 \mathrm{~h}$ of incubation, the supernatant of mixture was reacted with reaction mixture of kit in a ratio of $1: 1$ at room temperature for $30 \mathrm{~min}$. The absorbance of each well was measured at $490 \mathrm{~nm}$ using a microplate reader.

\section{Statistical analysis}

The results are presented as the mean \pm standard deviation (SD). The statistical significance was analyzed by one-way analysis of variance (ANOVA), followed by Duncan's multiple range test using the IBM SPSS program (IBM Corporation, Armonk, NY, USA). Statistical significance was set at $P$-values of less than 0.05 .

\section{Results and Discussion}

\section{DPPH radical scavenging activity of the EtOH extract and four fractions of PT}

The DPPH radical scavenging assay is a widely used method for evaluating in vitro antioxidant activity [22]. DPPH is a stable free radical with a violet color that is absorbed by EtOH solution. When DPPH solution is mixed with a substance that can donate a hydrogen atom such as an antioxidant, it is converted to the reduced form with a loss of color [23]. As shown in Table 1, we confirmed the DPPH radical scavenging activity of the EtOH extract and four fractions of PT. The EtOH extract and four fractions of PT showed dose-dependent elevations in DPPH radical scavenging activity. In particular, the EtOAc fraction of PT showed DPPH radical scavenging activities of 83.43 and $87.12 \%$ at concentrations of 50 and $100 \mu \mathrm{g} / \mathrm{mL}$, respectively. Meanwhile, ascorbic acid is widely used as a positive control for evaluation of antioxidant activity [24]. Previous study reported that ascorbic

Table 1 DPPH radical scavenging activity of Populus tomentiglandulosa

\begin{tabular}{|c|c|c|c|c|c|}
\hline \multirow{2}{*}{$\begin{array}{l}\text { Treatment } \\
(\mu \mathrm{g} / \mathrm{mL})\end{array}$} & \multicolumn{5}{|c|}{ DPPH radical scavenging activity $(\%)$} \\
\hline & EtOH ext. & $\mathrm{BuOH}$ fr. & EtOAc fr. & $\mathrm{CHCl}_{3}$ fr. & Hexane fr. \\
\hline 1 & $1.28 \pm 1.73^{\mathrm{d}}$ & $12.66 \pm 2.10^{\mathrm{d}}$ & $19.65 \pm 3.52^{d}$ & $9.41 \pm 2.96^{\mathrm{c}}$ & - \\
\hline 10 & $30.01 \pm 1.73^{\mathrm{c}}$ & $27.33 \pm 3.57^{\mathrm{c}}$ & $56.90 \pm 2.82^{\mathrm{c}}$ & $10.43 \pm 2.75^{\mathrm{c}}$ & $11.48 \pm 1.96^{\mathrm{c}}$ \\
\hline 50 & $56.99 \pm 2.86^{\mathrm{b}}$ & $72.83 \pm 1.94^{\mathrm{b}}$ & $83.43 \pm 2.68^{\mathrm{b}}$ & $32.82 \pm 1.23^{\mathrm{b}}$ & $33.66 \pm 0.71^{b}$ \\
\hline 100 & $76.84 \pm 1.11^{\mathrm{a}}$ & $81.61 \pm 1.72^{\mathrm{a}}$ & $87.12 \pm 1.37^{\mathrm{a}}$ & $41.54 \pm 1.33^{\mathrm{a}}$ & $51.35 \pm 2.11^{\mathrm{a}}$ \\
\hline $\mathrm{IC}_{50}(\mu \mathrm{g} / \mathrm{mL})$ & $25.57 \pm 0.60$ & $15.75 \pm 0.70$ & $6.98 \pm 0.44$ & $300.97 \pm 10.03$ & $132.63 \pm 6.37$ \\
\hline
\end{tabular}

Values are means \pm SD. The different letters $(\mathrm{a}-\mathrm{d})$ are significantly different $(p<0.05)$ by Duncan's multiple range test. IC $\mathrm{C}_{50}$ means the concentration $(\mu \mathrm{g} / \mathrm{mL})$ required to scavenge DPPH radical formation by $50 \%$. EtOH ext.: ethanol extract, BuOH fr.: $n$-butanol fraction, EtOAc fr.: ethyl acetate fraction, $\mathrm{CHCl}_{3}$ fr.: chloroform fraction, Hexane fr.: $n$-hexane fraction 
Table $2{ }^{\circ} \mathrm{OH}$ radical scavenging activity of Populus tomentiglandulosa

\begin{tabular}{|c|c|c|c|c|c|}
\hline \multirow{2}{*}{$\begin{array}{l}\text { Treatment } \\
(\mu \mathrm{g} / \mathrm{mL})\end{array}$} & \multicolumn{5}{|c|}{${ }^{\circ} \mathrm{OH}$ radical scavenging activity $(\%)$} \\
\hline & EtOH ext. & BuOH fr. & EtOAc fr. & $\mathrm{CHCl}_{3}$ fr. & Hexane fr. \\
\hline 1 & $14.48 \pm 1.30^{\mathrm{d}}$ & $13.18 \pm 0.54^{\mathrm{c}}$ & $33.53 \pm 0.30^{\mathrm{c}}$ & $33.78 \pm 1.59^{d}$ & $23.24 \pm 0.59^{d}$ \\
\hline 10 & $72.93 \pm 1.47^{\mathrm{c}}$ & $73.88 \pm 1.43^{\mathrm{b}}$ & $74.46 \pm 0.47^{\mathrm{b}}$ & $69.85 \pm 1.28^{\mathrm{c}}$ & $70.93 \pm 0.40^{\mathrm{c}}$ \\
\hline 50 & $86.69 \pm 0.44^{\mathrm{b}}$ & $89.58 \pm 1.57^{\mathrm{a}}$ & $85.38 \pm 0.88^{\mathrm{a}}$ & $86.00 \pm 0.20^{\mathrm{b}}$ & $89.44 \pm 0.81^{b}$ \\
\hline 100 & $89.02 \pm 1.43^{\mathrm{a}}$ & $88.41 \pm 1.40^{\mathrm{a}}$ & $86.02 \pm 0.49^{\mathrm{a}}$ & $89.81 \pm 1.08^{\mathrm{a}}$ & $97.89 \pm 0.74^{\mathrm{a}}$ \\
\hline $\mathrm{IC}_{50}(\mu \mathrm{g} / \mathrm{mL})$ & $6.18 \pm 0.15$ & $6.23 \pm 0.09$ & $3.11 \pm 0.02$ & $3.12 \pm 0.08$ & $4.35 \pm 0.04$ \\
\hline
\end{tabular}

Values are means $\pm \mathrm{SD}$. The different letters $(\mathrm{a}-\mathrm{d})$ are significantly different $(p<0.05)$ by Duncan's multiple range test. IC ${ }_{50}$ means the concentration $(\mu \mathrm{g} / \mathrm{mL})$ required to scavenge ${ }^{\circ} \mathrm{OH}$ radical formation by $50 \%$. EtOH ext.: ethanol extract, BuOH fr.: $n$-butanol fraction, EtOAc fr.: ethyl acetate fraction, $\mathrm{CHCl}_{3}$ fr.: chloroform fraction, Hexane fr.: $n$-hexane fraction

Table $3 \mathrm{O}_{2}^{-}$radical scavenging activity of Populus tomentiglandulosa

\begin{tabular}{|c|c|c|c|c|c|}
\hline \multirow{2}{*}{$\begin{array}{l}\text { Treatment } \\
(\mu \mathrm{g} / \mathrm{mL})\end{array}$} & \multicolumn{5}{|c|}{$\mathrm{O}_{2}^{-}$radical scavenging activity $(\%)$} \\
\hline & EtOH ext. & $\mathrm{BuOH}$ fr. & EtOAc fr. & $\mathrm{CHCl}_{3}$ fr. & Hexane fr. \\
\hline 1 & - & - & $11.10 \pm 1.67^{\mathrm{c}}$ & - & - \\
\hline 10 & $15.25 \pm 1.60^{\mathrm{c}}$ & $4.36 \pm 1.99^{c}$ & $12.83 \pm 3.58^{\mathrm{c}}$ & $2.32 \pm 3.05^{\mathrm{c}}$ & $10.56 \pm 1.83^{b}$ \\
\hline 50 & $41.48 \pm 2.55^{\mathrm{b}}$ & $42.00 \pm 1.83^{b}$ & $50.72 \pm 4.74^{\mathrm{b}}$ & $13.08 \pm 4.62^{\mathrm{b}}$ & $38.85 \pm 1.43^{\mathrm{a}}$ \\
\hline 100 & $44.07 \pm 1.21^{\mathrm{a}}$ & $64.46 \pm 1.65^{\mathrm{a}}$ & $66.07 \pm 1.64^{\mathrm{a}}$ & $25.20 \pm 1.48^{\mathrm{a}}$ & - \\
\hline $\mathrm{IC}_{50}(\mu \mathrm{g} / \mathrm{mL})$ & $120.53 \pm 4.47$ & $57.65 \pm 2.37$ & $39.99 \pm 2.14$ & $4817.04 \pm 507.77$ & - \\
\hline
\end{tabular}

Values are means \pm SD. The different letters $(\mathrm{a}-\mathrm{d})$ are significantly different $(p<0.05)$ by Duncan's multiple range test. IC ${ }_{50}$ means the concentration $(\mu \mathrm{g} / \mathrm{mL})$ required to scavenge $\mathrm{O}_{2}^{-}$radical formation by $50 \%$. EtOH ext.: ethanol extract, BuOH fr.: $n$-butanol fraction, EtOAc fr.: ethyl acetate fraction, $\mathrm{CHCl}_{3}$ fr.: chloroform fraction, Hexane fr.: $n$-hexane fraction

acid showed $\mathrm{IC}_{50}$ value of $8.21 \mu \mathrm{g} / \mathrm{mL}$ in DPPH radical scavenging activity [24]. The EtOAc fraction of PT had the lowest $\mathrm{IC}_{50}$ value $(6.98 \mu \mathrm{g} / \mathrm{mL})$ for DPPH radical scavenging activity among the extract and other fractions. These results indicated that the EtOAc fraction of PT had higher DPPH radical scavenging activity than the extract and other fractions.

\section{'OH radical scavenging activity of the EtOH extract and four fractions of PT}

The photo-Fenton reaction is a reaction that photoproduced Fe (II) reacts with $\mathrm{H}_{2} \mathrm{O}_{2}$ to reduce to $\mathrm{Fe}$ (III) and generate ${ }^{\circ} \mathrm{OH}$ radicals $[25,26]$. ${ }^{\circ} \mathrm{OH}$ radicals have a highly reactive property and can cause damage to essential cell components such as mitochondria, DNA, and cell membranes [27]. Therefore, ${ }^{\circ} \mathrm{OH}$ radicals have been known to play a role in many diseases such as aging, rheumatoid arthritis, and neurodegenerative diseases [28]. The ${ }^{\circ} \mathrm{OH}$ radical scavenging activity of the EtOH extract and four fractions of PT is shown in Table 2. The EtOH extract and four fractions of PT dose-dependently increased the ${ }^{\circ} \mathrm{OH}$ radical scavenging activity at concentrations of $1,10,50$, and $100 \mu \mathrm{g} / \mathrm{mL}$. In particular, the $\mathrm{IC}_{50}$ value of the EtOAc and $\mathrm{CHCl}_{3}$ fractions of PT were 3.11 and $3.12 \mu \mathrm{g} / \mathrm{mL}$, respectively, showing the strongest ${ }^{\circ} \mathrm{OH}$ radical scavenging activity compared to the extract and other fractions. Moreover, these values are comparable to ascorbic acid, which showed the $\mathrm{IC}_{50}$ value of $1.06 \mu \mathrm{g} / \mathrm{mL}$ for ${ }^{\circ} \mathrm{OH}$ radical scavenging activity in previous study [29]. These findings suggested that the
EtOAc and $\mathrm{CHCl}_{3}$ fractions of PT showed higher ${ }^{\circ} \mathrm{OH}$ radical scavenging activity than the extract and other fractions.

\section{$\mathrm{O}_{2}^{-}$radical scavenging activity of the EtOH extract and four fractions of PT}

$\mathrm{O}_{2}{ }^{-}$radicals are formed by NADH phosphate oxidase, which is a membrane-bound enzyme that reduces the one-electron of free molecular oxygen [30]. Nishikimi et al [31] reported that NADH and PMS formed $\mathrm{O}_{2}^{-}$radicals in vitro and then reacted with NBT to form a blue color. $\mathrm{O}_{2}^{-}$radicals are involved in the production of other ROS such as ${ }^{\circ} \mathrm{OH}$ radicals and $\mathrm{H}_{2} \mathrm{O}_{2}$, leading to oxidative damage in the body [32,33]. The $\mathrm{O}_{2}{ }^{-}$radical scavenging activity of the EtOH extract and four fractions of PT is shown in Table 3. The $\mathrm{BuOH}$ and EtOAc fractions of PT showed more than $60 \%$ $\mathrm{O}_{2}^{-}$radical scavenging activity at a concentration of $100 \mu \mathrm{g} / \mathrm{mL}$. Especially, the EtOAc fractions of PT showed the lowest $\mathrm{IC}_{50}$ value of $39.99 \mu \mathrm{g} / \mathrm{mL}$, which suggests that it had the highest $\mathrm{O}_{2}{ }^{-}$ radical scavenging activity among the extract and other fractions. In previous study, ascorbic acid exhibited an $\mathrm{IC}_{50}$ value of 20.72 $\mu \mathrm{g} / \mathrm{mL}$ in $\mathrm{O}_{2}^{-}$radical scavenging activity [24]. Therefore, our findings indicated that EtOH extract and four fractions of PT has antioxidant activity by indicating the $\mathrm{DPPH},{ }^{\circ} \mathrm{OH}$, and $\mathrm{O}_{2}{ }^{-}$radical scavenging activities under in vitro. Particularly, the EtOAc fraction of PT showed the strongest in vitro antioxidant activity among the extract and other fractions, suggesting that it was an active fraction of PT. 


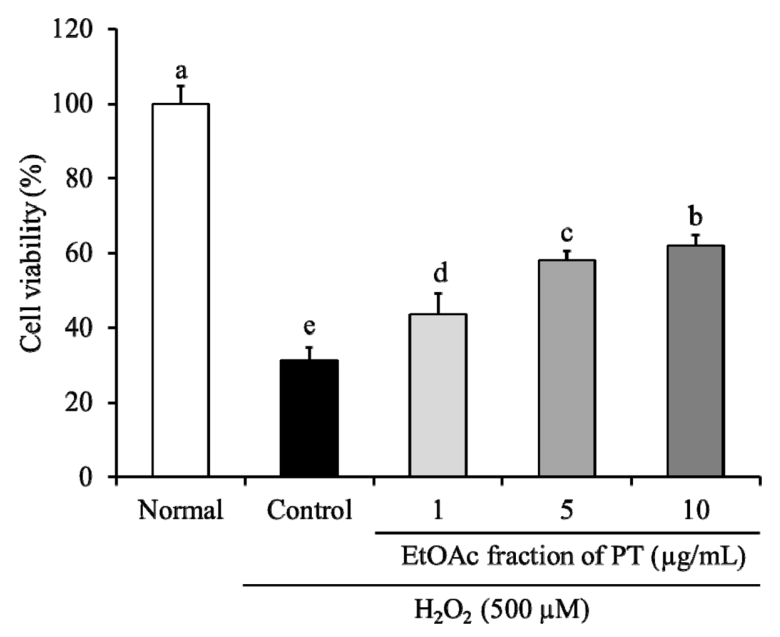

Fig. 1 Effect of the EtOAc fraction of Populus tomentiglandulosa on cell viability in $\mathrm{H}_{2} \mathrm{O}_{2}$-treated SH-SY5Y cells. The results are expressed as the mean $\pm \mathrm{SD}$. The different letters (a-e) among the groups indicate significant differences $(p<0.05)$ by Duncan's multiple range test

Effect of the EtOAc fraction of PT on cell viability in $\mathrm{H}_{2} \mathrm{O}_{2}$ treated SH-SY5Y cells

SH-SY5Y cells are widely used for studying neuronal damage induced by oxidative stress under cellular system [34]. $\mathrm{H}_{2} \mathrm{O}_{2}$, a ROS, is broadly used as an inducer of oxidative stress [35]. Kang et al. [36] reported that treatment with $\mathrm{H}_{2} \mathrm{O}_{2}$ significantly reduced cell viability in SH-SY5Y neuronal cells, showing that oxidative stress induced by $\mathrm{H}_{2} \mathrm{O}_{2}$ caused neuronal cell death. To evaluate the neuroprotective effect of the EtOAc fraction of PT on neuronal cell death caused by oxidative stress, we measured the cell viability in $\mathrm{H}_{2} \mathrm{O}_{2}$-treated neuronal SH-SY5Y cells. As shown in Fig. 1, cell viability in the $\mathrm{H}_{2} \mathrm{O}_{2}$-treated control group significantly declined to $31.31 \%$ compared to the non-treated normal group (100\%). This result showed that treatment with $\mathrm{H}_{2} \mathrm{O}_{2}$ induced neuronal oxidative stress in SH-SY5Y cells. However, treatment with the EtOAc fraction of PT increased the cell viability in a dosedependent manner compared to the $\mathrm{H}_{2} \mathrm{O}_{2}$-treated control group. Especially, the cell viability increased to 57.99 and $61.89 \%$ at concentrations of 5 and $10 \mu \mathrm{g} / \mathrm{mL}$, respectively. Our results showed that the EtOAc fraction of PT had a neuroprotective effect on neuronal cell death by increasing cell viability in oxidative stressinduced SH-SY5Y cells.

\section{Effect of the EtOAc fraction of PT on ROS production in $\mathrm{H}_{2} \mathrm{O}_{2}$-treated SH-SY5Y cells}

DCFH-DA is a non-fluorescent molecule, but when it reacts with ROS, it is oxidized and converted to dichlorofluorescein (DCF) [37]. DCF is highly fluorescent and can be measured by fluorescence analysis. The DCFH-DA assay estimates the level of intracellular ROS using this principle [37]. Overproduction of ROS induces oxidative stress in neuronal cells, resulting in neuronal apoptosis, which directly contributes to neurodegenerative diseases [38]. In addition, increases in ROS levels were observed in the brain of patients with neurodegenerative diseases such as Alzheimer's disease [39]. According to Law et al. [35], $\mathrm{H}_{2} \mathrm{O}_{2}$-treated SHSY5Y cells had significantly elevated ROS levels compared to non-treated cells. To confirm the inhibition of the production of ROS by the EtOAc fraction of PT, we measured the production of ROS in $\mathrm{H}_{2} \mathrm{O}_{2}$-treated neuronal SH-SY5Y cells. As shown in Fig. $2 \mathrm{~A}$, treatment with $500 \mu \mathrm{M} \mathrm{H}_{2} \mathrm{O}_{2}$ increased ROS production for 60 min compared to the non-treated normal group. Moreover, the production of ROS at 60 min was significantly increased in the $\mathrm{H}_{2} \mathrm{O}_{2}$-induced control group compared to the normal group, suggesting that $\mathrm{H}_{2} \mathrm{O}_{2}$ induced oxidative stress by increasing ROS
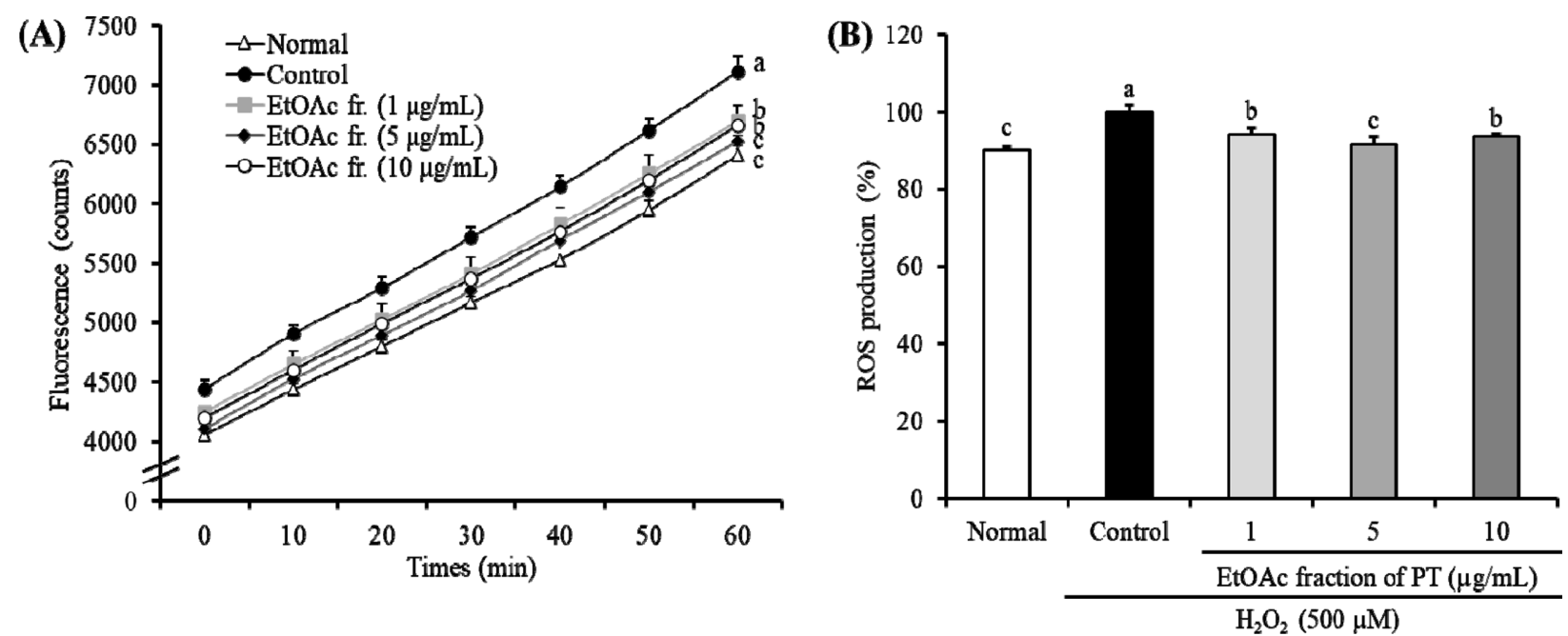

Fig. 2 Effect of the EtOAc fraction of Populus tomentiglandulosa on ROS production in $\mathrm{H}_{2} \mathrm{O}_{2}$-treated SH-SY5Y cells. (A) Time-course of changes in DCFH fluorescence intensity over $60 \mathrm{~min}$. (B) Percentage of ROS production at $60 \mathrm{~min}$. The results are expressed as the mean $\pm \mathrm{SD}$. The different letters $(\mathrm{a}-\mathrm{c})$ among groups indicate significant differences $(p<0.05)$ by Duncan's multiple range test 


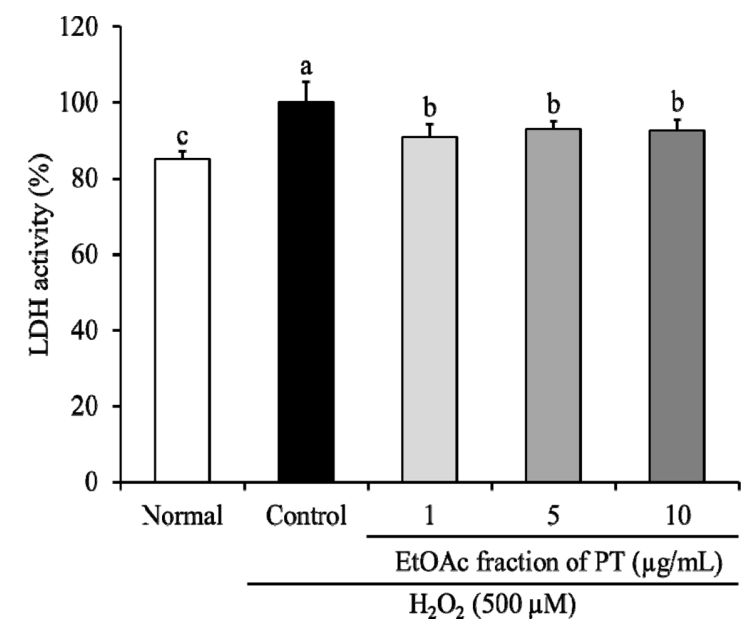

Fig. 3 Effect of the EtOAc fraction of Populus tomentiglandulosa on LDH release in $\mathrm{H}_{2} \mathrm{O}_{2}$-treated $\mathrm{SH}-\mathrm{SY} 5 \mathrm{Y}$ cells. The results are expressed as the mean $\pm \mathrm{SD}$. The different letters (a-c) among groups indicate significant differences $(p<0.05)$ by Duncan's multiple range test

levels in the SH-SY5Y cells (Fig. 2B). In contrast, treatment with the EtOAc fraction of PT at concentrations of 1, 5, and $10 \mu \mathrm{g} / \mathrm{mL}$ significantly attenuated the production of ROS compared to the $\mathrm{H}_{2} \mathrm{O}_{2}$-treated control group. In particular, treatment with the EtOAc fraction of PT at $5 \mu \mathrm{g} / \mathrm{mL}$ decreased ROS production to $91.66 \%$, similar to that of the normal group. These findings suggested that the EtOAc fraction of PT suppressed the oxidative stress induced by $\mathrm{H}_{2} \mathrm{O}_{2}$ by reducing the ROS levels in SH-SY5Y cells.

\section{Effect of the EtOAc fraction of PT on $\mathrm{LDH}$ release in $\mathrm{H}_{2} \mathrm{O}_{2-}$ treated SH-SY5Y cells}

$\mathrm{LDH}$ is an enzyme present in the cytoplasm of most tissues including the brain. The organ and extracellular levels of LDH are used as an indicator of cell damage [40]. A previous study demonstrated that $\mathrm{H}_{2} \mathrm{O}_{2}$ exposure increased the $\mathrm{LDH}$ release induced by oxidative damage in SH-SY5Y cells [41]. To confirm the neuroprotective effect on oxidative stress, we investigated the effect of the EtOAc fraction of PT on LDH release in $\mathrm{H}_{2} \mathrm{O}_{2}$-treated SH-SY5Y cells (Fig. 3). The $\mathrm{H}_{2} \mathrm{O}_{2}$-treated control group had significantly increased LDH release $(100 \%)$ compared to the nontreated normal group of $85.13 \%$. Treatment with the EtOAc fraction of PT at doses of 1,5 , and $10 \mu \mathrm{g} / \mathrm{mL}$ significantly decreased the LDH release compared to the $\mathrm{H}_{2} \mathrm{O}_{2}$-treated control group. Therefore, we suggested that PT prevented the neuronal damage caused by oxidative stress by decreasing LDH release.

Previous studies have reported that EtOH extract of PT contains several active compounds including catechin, caffeic acid $p$ coumaric acid, chlorogenic acid, and gallic acid, and these compounds are widely known to have antioxidant and neuroprotective activities [42-45]. According to Cho et al. [42], catechin and gallic acid have been shown to exhibit DPPH radical scavenging activity ( $\mathrm{IC}_{50}$ values of 0.85 and $0.28 \mu \mathrm{g} / \mathrm{mL}$, respectively). In addition, $p$-coumaric acid has in vitro antioxidant activity by DPPH and ABTS radical scavenging activities [43]. Moreover, catechin protected neuronal oxidative stress by decreasing ROS production and had radical scavenging activity in $\mathrm{H}_{2} \mathrm{O}_{2}$-induced neuronal cells [44]. Chlorogenic acid ameliorated oxidative stressinduced neuronal toxicity by inhibition of ROS and up-regulation of antioxidant enzymes in neuronal cells [45]. Therefore, PT could show in vitro antioxidant and neuroprotective effect against oxidative stress by their active compounds.

In summary, the EtOH extract and four fractions of PT showed in vitro antioxidant activity in the $\mathrm{DPPH},{ }^{\circ} \mathrm{OH}$, and $\mathrm{O}_{2}^{-}$radical scavenging assays. In particular, the EtOAc fraction of PT had the strongest in vitro antioxidant activity among the extract and other fractions of PT. Furthermore, the EtOAc fraction of PT had a neuroprotective effect against oxidative stress by regulating ROS production and $\mathrm{LDH}$ release in $\mathrm{H}_{2} \mathrm{O}_{2}$-induced SH-SY5Y cells. Therefore, this study supported that PT can be used as a natural agent for protection against oxidative stress in the brain.

Acknowledgments This work was supported by a National Research Foundation of Korea (NRF) grant funded by the Korea government (MSIT) (No.2019R1F1A1054676).

\section{References}

1. Cañedo LE, Todd LE, Packer L, Jaz J (1988) Cell function and disease. Springer, Boston

2. Finaud J, Lac G, Filaire E (2006) Oxidative Stress. Sports Med 36: 327 358

3. Ahmad W, Ijaz B, Shabbiri K, Ahmed F, Rehman S (2017) Oxidative toxicity in diabetes and Alzheimer's disease: mechanisms behind ROS/ RNS generation. J Biomed Sci 24: 76

4. Sies H (1997) Oxidative stress: oxidants and antioxidants. Exp Physiol 82: 291-295

5. Wu D, Cederbaum AI (2003) Alcohol, oxidative stress, and free radical damage. Alcohol Res Health 27: 277-284

6. Aruoma OI (1998) Free radicals, oxidative stress, and antioxidants in human health and disease. J Am Oil Chem Soc 75: 199-212

7. Dasuri K, Zhang L, Keller JN (2013) Oxidative stress, neurodegeneration, and the balance of protein degradation and protein synthesis. Free Radic Biol Med 62: 170-185

8. Halliwell B (2006) Oxidative stress and neurodegeneration: where are we now? J Neurochem 97: 1634-1658

9. Gilgun-Sherki Y, Melamed E, Offen D (2001) Oxidative stress inducedneurodegenerative diseases: the need for antioxidants that penetrate the blood brain barrier. Neuropharmacol 40: 959-975

10. Kwak JH, Oh YS (2003) Evaluation of Populus alba X glandulosa as raw material of particleboard. J Korean For Soc 92: 140-144

11. Zhang XF, Thuong PT, Min BS, Ngoc TM, Hung TM, Lee IS, Na MK, Seong YH, Song KS, Bae KH (2006) Phenolic glycosides with antioxidant activity from the stem bark of Populus davidiana. J Nat Prod 69: 1370-1373

12. Zhang XF, Hung TM, Phuong PT, Ngoc TM, Min BS, Song KS, Seong $\mathrm{YH}$, Bae KH (2006) Anti-inflammatory activity of flavonoids from Populus davidiana. Arch Pharm Res 29: 1102-1108

13. Debbache-Benaida N, Atmani-Kilani D, Schini-Keirth VB, Djebbli N, Atmani D (2013) Pharmacological potential of Populus nigra extract as 
antioxidant, anti-inflammatory, cardiovascular and hepatoprotective agent Asian Pac J Trop Biomed 3: 697-704

14. Choi SI, Hwang SJ, Lee OH, Kim JD (2020) Antioxidant activity and component analysis of Populus tomentiglandulosa extract. Korean J Food Sci Technol 52: 119-124

15. Lee TK, Park JH, Ahn JH, Kim H, Song M, Lee JC, Kim JD, Jeon YH, Choi HJ, Lee CH, Hwang IK, YAN BC, Won MH, Kang IJ (2019) Pretreatment of Populus tomentiglandulosa protects hippocampal CA1 pyramidal neurons from ischemia-reperfusion injury in gerbils via increasing SODs expressions and maintaining BDNF and IGF-I expressions. Chin J Nat Med 17: 424-434

16. Park JH, Lee TK, Ahn JH, Shin BN, Cho JH, Kim IH, Lee JC, Kim JD, Lee YJ, Kang IJ, Hong S, Kim YH, Jeon YH, Lee YL, Won MH (2017) Pre-treated Populus tomentiglandulosa extract inhibits neuronal loss and alleviates gliosis in the gerbil hippocampal CA1 area induced by transient global cerebral ischemia. Anat Cell Biol 50: 284-292

17. Hatano T, Edamatsu R, Hiramatsu M, Mori A, Fujita Y, Yasuhara T, Yoshida T, Okuda T (1989) Effects of the interaction of tannins with coexisting substances. Effects of tannins and related polyphenols on superoxide anion radical, and on 1,1-diphenyl-2-picrylhydrazyl radical. Chem Pharm Bull 37: 2016-2021

18. Chung SK, Osawa T, Kawakishi S (1997) Hydroxyl radical-scavenging effects of spices and scavengers from brown mustard (Brassica nigra). Biosci Biotechnol Biochem 61: 118-123

19. Ewing JF, Janero DR (1995) Microplate superoxide dismutase assay emplying a nonenzymatic superoxide generator. Anal Biochem 232: 243-248

20. Mosmann T (1983) Rapid colorimetric assay for cellular growth and survival: application to proliferation and cytotoxicity assays. J Immunol Methods 65: 55-63

21. Cathcart R, Schwiers E, Ames BN (1983) Detection of picomole levels of hydroperoxides using a fluorescent dichlorofluorescein assay. Anal Biochem 134: 111-116

22. Sharma OP, Bhat TK (2009) DPPH antioxidant assay revisited. Food Chem 113: 1202-1205

23. Kedare SB, Singh RP (2011) Genesis and development of DPPH method of antioxidant assay. J Food Sci Technol 48: 412-422

24. Patel Rajesh M, Patel Natvar J (2011) In vitro antioxidant activity of coumarin compounds by DPPH, super oxide and nitric oxide free radical scavenging methods. J Adv Pharm Educ Res 1: 52-68

25. Zepp RG, BC Faust BC, Hoigne J (1992) Hydroxyl radical formation in aqueous reactions ( $\mathrm{pH} 3-8$ ) of iron (II) with hydrogen peroxide: the photo-Fenton reaction. Environ Sci Technol 26: 313-319

26. Southworth BA, Voelker BM (2003) Hydroxyl radical production via the photo-Fenton reaction in the presence of fulvic acid. Environ Sci Technol 37: $1130-1136$

27. Cadet J, Delatour T, Douki T, Gasparutto D, Pouget JP, Ravanat JL, Sauvaigo S (1999) Hydroxyl radicals and DNA base damage. Mutat Res 424: 9-21

28. Cheng FC, Jen JF, Tsai TH (2002) Hydroxyl radical in living systems and its separation methods. J Chromatogr B 781: 481-496

29. Wang Q, Lee AY, Choi JM, Lee DG, Kim HY, Lee S, Cho EJ (2014) In vitro radical scavenging effect and neuroprotective activity from oxidative stress of Petasites japonicas. Kor J Pharmacogn 45: 147-153

30. Chun OK, Kim DO, Lee CY (2003) Superoxide radical scavenging activity of the major polyphenols in fresh plums. J Agric Food Chem 51: 8067-8072

31. Nishikimi N, Rao NA, Yagi K (1972) The occurrence of superoxide anion in the reaction of reduced phenazine methosulfate and molecular oxygen. Biochem Biophys Res Commun 46: 849-854

32. Benov L (2001) How superoxide radical damages the cell. Protoplasma 217: 33-36

33. Chung JH, Jeon IS (2011) Antioxidative activities of methanol extracts from different parts of Chrysanthemum zawadskii. J Food Pre 18: 739 745

34. Fordel E, Thijs L, Martinet W, Lenjou M, Laufs T, Bockstaele DV, Moens L, Dewilde S (2006) Neuroglobin and cytoglobin overexpression protects human SH-SY5Y neuroblastoma cells against oxidative stressinduced cell death. Neurosci Lett 410: 146-151

35. Law BNT, Ling APK, Koh RY, Chye SM, Wong YP (2014) Neuroprotective effects of orientin on hydrogen peroxide-induced apoptosis in SH-SY5Y cells. Mol Med Rep 9: 947-954

36. Kang SS, Lee JY, Choi YK, Kim GS, Han BH (2004) Neuroprotective effects of flavones on hydrogen peroxide-induced apoptosis in SH-SY5Y neuroblostoma cells. Bioorg Med Chem Lett 14: 2261-2264

37. Rajneesh J, Pathak J, Chatterjee A, Singh SP, Sinha RP (2017) Detection of reactive oxygen species (ROS) in cyanobacteria using the oxidantsensing probe 2',7'-dichlorodihydrofluorescein diacetate (DCFH-DA). Bio Protoc 7: e2545

38. Loh KP, Huang SH, De Silva R, Tan BK, Zhu YZ (2006) Oxidative stress: Apoptosis in neuronal injury. Curr Alzheimer Res 3: 327-337

39. Andersen JK (2004) Oxidative stress in neurodegeneration: cause or consequence? Nat Med 10: S18-S25

40. Drent M, Cobben NA, Henderson RF, Wouters EF, Dieijen M (1996) Usefulness of lactate dehydrogenase and its isoenzymes as indicators of lung damage or inflammation. Eur Respir J 9: 1736-1742

41. Garcimartín A, Merino JJ, González MP, Sánchez-Reus MI, SánchezMuniz FJ, Bastida S, Benedí J (2014) Organic silicon protects human neuroblastoma SH-SY5Y cells against hydrogen peroxide effects. BMC Complement Altern Med 14: 384

42. Cho EJ, Yokozawa T, Rhyu DY, Kim SC, Shibahara N, Park JC (2003) Study on the inhibitory effects of Korean medicinal plants and their main compounds on the 1, 1-diphenyl-2-picrylhydrazyl radical. Phytomedicine 10: 544-551

43. Kiliç I, Yeşiloğlu Y (2013) Spectroscopic studies on the antioxidant activity of $p$-coumaric acid. Spectrochim Acta A Mol Biomol Spectrosc 115: 719-724

44. He J, Xu L, Le Yang XW (2018) Epigallocatechin gallate is the most effective catechin against antioxidant stress via hydrogen peroxide and radical scavenging activity. Med Sci Monit 24: 8198-8206

45. Pavlica S, Gebhardt R (2005) Protective effects of ellagic and chlorogenic acids against oxidative stress in PC12 cells. Free Radic Res 39: 1377-1390 